\title{
Research Design Proposal for Investigation of Site 41TV338 In the Barton Creek Drainage Travis County, Texas
}

Follow this and additional works at: https://scholarworks.sfasu.edu/ita

Part of the American Material Culture Commons, Archaeological Anthropology Commons, Environmental Studies Commons, Other American Studies Commons, Other Arts and Humanities Commons, Other History of Art, Architecture, and Archaeology Commons, and the United States History Commons

Tell us how this article helped you.

This Article is brought to you for free and open access by the Center for Regional Heritage Research at SFA ScholarWorks. It has been accepted for inclusion in Index of Texas Archaeology: Open Access Gray Literature from the Lone Star State by an authorized editor of SFA ScholarWorks. For more information, please contact cdsscholarworks@sfasu.edu. 


\section{Research Design Proposal for Investigation of Site 41TV338 In the Barton Creek Drainage Travis County, Texas}

\section{Licensing Statement}

This is a work produced for the Texas Department of Transportation (TxDOT) by the report producer. TxDOT and the report producer jointly own all rights, title, and interest in and to all intellectual property developed under TXDOT's contract with the report producer. The report may be cited and brief passages from this publication may be reproduced without permission provided that credit is given to both TXDOT and the report producer. Permission to reprint an entire chapter, section, figures or tables must be obtained in advance from either the Supervisor of the Archeological Studies Branch, Environmental Affairs Division, Texas Department of Transportation, 125 East 11th Street, Austin, Texas, 78701 or from the report producer. 
Research Design Proposal for Investigation of Site 41TV338

In the Barton Creek Drainage

Travis County, $\mathrm{T}$ ex a s

Texas

State Department of Highways and Public Transportation Highway Design Division

November 1983 
Research Design for Excavation of Archaeological Site 41 TV338

Site 41TV338, located in the west bank and terrace of Barton Creek west of Loop 360, was found in 1975. The SDHPT, during an archaeological survey in 1983, determined the site would be impacted by the present undertaking.

Because the area in the vicinity of the project is considered environmentally sensitive, very special construction specifications will be enforced during total implementation of the project. These specifications are designed to prohibit disruption of the natural environmental setting to the greatest degree possible. Most of the right of way acquired for construction of the highway facility is not to be touched during construction. Archaeological investigations will be subject to the same restrictions. These restrictions include limited access, the use of designated construction roadways, minimal disruption of the ground surface, and application of special erosion control techniques. The controlled archaeological investigations will be limited to 3 in. diameter auger tests along designated transects and excavation in only those portions of the site to be disturbed by construction of pier footings for the overhead bridge structures. The footings will be found in six rectangular areas measuring eight feet by twenty-three feet. Three of these footings are in areas containing archaeological deposits. One is the subject of the majority of the testing report and will be excavated completely. Testing and excavation, if warranted, will be performed on the other two which exhibit cultural deposits.

All archaeological activities will be performed in accordance with standard field techniques and as outlined in Part III of the Advisory Council on Historic Preservation's Handbook. Excavation of the 8 by $23 \mathrm{ft}$. areas will be performed in a meter grid pattern with findings dictating change of excavation techniques if warranted. Units will be dug by hand in arbitrary ten centimeter levels. All excavated material will be passed through a 0.25 in. hardware cloth screen with artifacts catalogued by unit and level. It is estimated that excavation will require six individuals and will be completed within two months. 
Curation of all data generated will be at the Department's archaeological laboratory until such time as all studies have been completed. Final disposition and curation of all data will be determined at the end of the analysis period. Laboratory analysis of findings may require up to a year with final publication issued approximately one year later. A draft document will be forwarded to the SHPO for review and comment prior to final publication. The manuscript will adhere to the Council of Texas Archaeologists Reports Standards Guidelines. Excavation, laboratory analysis and writing of the report will be performed by Mr. John W. Clark, Jr., of the Department's professional cultural resources staff under general supervision of Dr. Frank A. Weir, Director of Archaeological Studies for the Department.

Preliminary testing of archaeological Site 41 TV338 revealed at least two distinct cultural zones. A burned rock feature was found within each of these zones. No diagnostic material affiliated with either of these zones was recovered during testing. Due to the limited area of alluvial deposit sampled, neither depth or extent of occupation was determined. It is anticipated that additional information will be uncovered early in the proposed excavation which will lead to declaration of affiliation hypotheses. The value of 41 TV338 lies in the potential for recovery of information from undisturbed deposits.

Although the absence of organic residue recovered from the site during testing has proven to be a limiting factor in terms of delineation of temporal affiliation (i.e. C14 dating), specific soil analyses are planned. Soil samples will be taken for fine screening and flotation studies. Analyses of recoverable microfauna, microflora, and pollen, are planned. Environmental results will prove to be of value if diagnostic and other datable materials are recovered.

Seasonality of the occupation, past environmental conditions, and subsistence strategies along the Barton Creek drainage are major topics which can be addressed during excavation. As with any dynamic approach to research, dating the occupation, along with the other topics mentioned, will be refined as the data are collected. Some specific research directions regarding 41 TV338 follow. 
1. The major feature found during testing lies at a depth of 1.6 meters beneath the ground surface, and may be a large hearth. A survey of the literature indicates that only two prehistoric sites have been investigated along the Barton Creek drainage: The Crumley Site, 41TV86 (Kelly 1961), and the Barton Springs Site, 41TV2, excavated in 1928 by J. E. Pearce of the University of Texas (Prewitt n.d.). Evidently, the excavation notes on 41TV2 have been lost and little has been published about the site. Nevertheless, some comparisons between 41 TV338 and other sites in the area may prove useful to indicate what activities were carried out at 41TV338. Exploration and explanation of the large rock feature (no. 2), should answer such questions as to whether or not the feature contains a pit, whether it is overlapping hearths, just one hearth, or whether it is a hearth at all. Overlapping hearths would indicate perhaps episodal use of the area by earlier peoples or, the massive feature might be indicative of the Central Texas burned rock midden, usually associated with aggregates of people during the Middle and Late Archaic (Weir 1976, Prewitt 1982). Defining the structure, depth and associations of the feature will hopefully shed light on factors such as function, subsistence, chronology, and temporal variations between occupational zones.

2. Depositional stratigraphic records for the Barton Creek area have not been established. Since the alluvial and colluvial deposit at site 41TV338 is substantial, and since the site is located in a definite and well defined area of depositional soils created by overbank flooding of Barton Creek in the distant past (Soil Conservation Service 1974), information regarding past depositional and erosional patterns will be sought during excavation by discrete augering using a 3 in. diameter instrument along designated axes within the right of way. It is hoped that the analyses of augering tests will increase our understanding of factors (geological and cultural) which dictated site placement in prehistoric times.

3. Through excavation of the two occupational zones, hopefully, a chronology for the site can be formulated. This, in turn, can be compared to the chronological constructs which exist for the Central Texas region. To date no temporally diagnostic material has been recovered through excavation at the site. But the recovery of biface fragments and other general purpose lithic tools indicate that they do exist at Site 41 TV 338 and the possibility of 
recovering datable materials is high. Since no bone, charcoal or other organics have been discovered during testing which might shed light on the temporal factors of the site, the use of thermoluminescence as a dating tool will be considered as an alternative should C14 or temporally diagnostic tools not be available.

4. Comparative analysis of artifacts and data from this site with material from other sites in the area is proposed. Data correlation with other sites along Barton Creek, above and below the fault lines, as well as other sites in the area, will serve to bring into focus aspects of subsistence strategies, chronology, and function, and will also serve to manifest a security in our knowledge gained from site 41 TV338. 